\title{
A BIBLIOGRAPHY OF SÜRYÂNI PERIODICALS IN OTTOMAN TURKISH
}

\author{
BENJAMIN TRIGONA-HARANY
}

\section{SYRIAC CHRISTIAN JOURNALISM}

There have been, over the years, numerous studies that have addressed aspects of the journalistic production of the Assyrians living in western Persia as well as their emigrant communities in the United States and elsewhere. ${ }^{1}$ However, the parallel story of the Ottoman Süryan $\imath^{2}$ has until recently been more difficult to trace. But, with new sources having come to light and with greater interest from Ottomanists, it has become possible to outline some precise information concerning these periodicals and to understand them in their proper historical context.

${ }^{1}$ See, for example, Eden Naby, "The Assyrians of Iran: Reunification of a 'Millat,' 1906-1914," International Journal of Middle Eastern Studies 8, no. 2 (April 1977): 237-249, Gabriele Yonan, Journalismus bei den Assyrern. Ein Überblick von seinen Anfängen bis zur Gegenwart (Berlin: Zentralverband der Assyrischen Vereinigungen in Deutschland und Mitteleuropa, 1985), Abdulmesih BarAbrahem, "The 'Question of Assyrian Journalism' Revisited," Journal of the Assyrian Academic Society 9, no. 1 (April 1995): 3-7 or Yoab Benjamin, "Assyrian Journalism. A 140-Year Experience," Journal of the Assyrian Academic Society 7, no. 2 (November 1993): 1-28.

${ }^{2}$ I prefer to use the term Süryanî to refer to the members of the Syriac Orthodox Church along with its converts to the Catholicism and Protestantism since this replicates the usage of the people in question. Unfortunately, there is no unambiguous English translation of this word available, so we are forced to rely on this Ottoman Turkish borrowing from Arabic. 
Unlike the situation in Persia, the sudden establishment of numerous journals and newspapers can not be traced to missionary intervention; instead the impetus derived from political events in the Ottoman Empire, specifically the Young Turk revolution of 1908, which brought about the restoration of constitutional rule, parliamentary elections and a relaxation of the censorship that had characterised the reign of Sultan Abdülhamîd. Although these events had been greeted with much celebration in the streets of the major Ottoman cities, the new Young Turk government had its opponents. In 1909 a counter-revolution began in Istanbul; Christians-primarily Armenians, but also Süryânı̂-were massacred in Adana and its environs. But to renewed acclaim, the Young Turk party, the Ittihâd ve Terakkề Cemiyeti (Committee for Union and Progress), put down this challenge with the support of loyal military units. Sultan Abdülhamîd was accused of collusion with the rebels and found himself deposed and exiled to Salonika.

We should not underestimate the impact of these events on the Süryânî and other non-Muslims. Publicly at least, the Young Turks re-embraced the policy of Ottomanism (Osmanll11k) by which all citizens of the Ottoman Empire, irrespective of religious affiliation, were to be considered equally under Ottoman law. Numerous Armenians, Greeks, and Jews represented their constituencies in the Ottoman parliament. ${ }^{3}$ Non-Muslims were now also subject to conscription into the army, something which was endorsed by Greek, Armenian and Süryânî leaders as a necessary step towards greater equality. ${ }^{4}$ The new Ottoman constitution was the symbol of the hopes and aspirations that the events of 1908 and 1909 bred within the Süryânî community; contemporary sources recount Süryânî participation in celebrations honouring the constitution and the new Sultan, Mehmed Reşâd, in places such as Mardin, Harput, and even the emigrant communities of Massachusetts.

For journalism in the Ottoman Empire, the 1908 revolution was a great boon, and within a few months the number of periodicals in the capital jumped to several times its pre-1908 figure. This trend was replicated in the provinces, where beforehand only a government newspaper (often appearing in Ottoman Turkish as

3 A Chaldean, Davûd Yûsufânî, was also elected as a representative for Mosul and became a member of a leading opposition party's inner circle.

${ }^{4}$ We know little about Süryân $̂$ participation in the Ottoman military. Just after the outbreak of World War I, however, the newspaper Intibâh did report on a student from Diyarbakir who was one of the top students at the military school in Istanbul and was on track to be a ranking officer. 
well as a local language such as Arabic, Armenian, or Greek) had usually been available. There had been a pre-1908 initiative to establish a printing press to publish books at the monastery of Deyrü'z-Zaferân outside of Mardin, but the Süryânî had no previous journalistic experience. Nevertheless, between 1909 and 1914, no less than six periodicals were established: three in Harput, two in Diyarbakır and one in Mardin..$^{5}$ In addition, Süryân̂ emigrants in the United States founded two further publications prior to 1914 and a handful more afterwards.

In the early years, the Süryân described not so much as newspapers but as journals, although this latter term was not what they used to describe themselves. ${ }^{6}$ Only in the 1920s do we come across a weekly that contained stories about current events and advertising. Prior to this time, publications had little of what could be described as news, especially if it did not specifically address the Süryânî community. Instead, earlier examples were more of a space for their editors to express themselves didactically and to engage in public exchanges with their readership.

Most of the early twentieth-century Süryânî periodicals were characterised by a reliance on Ottoman Turkish as a linguistic medium. ${ }^{7}$ Sometimes Ottoman Turkish would be employed exclusively and sometimes it was used in conjunction with Arabic, Syriac and, later, English, but in all of the pre-War instances, except $e l-$ Hikmet, the non-Turkish sections were considerably smaller in comparison. ${ }^{8}$ For the most part, all text was written in the Syriac alphabet although in some newspapers the Arabic or Ottoman Turkish portions could be in the Arabic script. Siffuro and Intibâh used both alphabets for Ottoman Turkish, and the latter even printed a primer for "Süryânı̂ desiring to read Turkish in Syriac letters." The phenomenon of a community writing Ottoman Turkish in its own alphabet was not unique to the Süryânî, with Ottoman Turkish-language literature having long appeared in the Armenian, Greek, and Hebrew alphabets. Unlike in the other cases, however, the transition from Arabic to Syriac was an easy one. The well-

5 There was probably a seventh, again in Harput.

${ }^{6}$ In Ottoman Turkish, the terms most often employed was the Italian gazete and, occasionally, the Arabic ceride (both meaning "newspaper"), rather than mecmûa ("journal, magazine, review").

${ }^{7}$ An exception not discussed here is The Aramean, a publication that targeted the Arabic-speaking Süryân̂, Maronites and Chaldeans.

${ }^{8} \mathrm{My}$ initial analysis of eight issues of Kevkeb Mednho, for example, found over $60 \%$ of articles in Ottoman Turkish, roughly $30 \%$ in Arabic and fewer than $10 \%$ in Syriac. 
established practice of writing Arabic with Syriac letters, known as Garshuni or Karshuni, provided Ottoman Turkish with a system in which there was an almost one-to-one relationship between the letters in both alphabets. To accommodate Ottoman Turkish, only the creation of four extra letters through the modification of existing letters was necessary.

The decision to use the Syriac alphabet appears to have been ideological rather than practical, a conclusion based both on the need for the guide printed in Intibâh and on the editorial appeals in Mürşid-i Âsûriyun for the Süryânı̂ who could not speak Syriac to at least employ the Syriac alphabet when writing in other languages. ${ }^{9}$ On the other hand, the use of the Ottoman Turkish language was an eminently practical choice. In the late Ottoman era, the Süryân $\hat{\imath}$ spoke different tongues-Arabic, Armenian, Kurdish or Turkishdepending on the region in which they resided. Only for those in Tur Abdin (Cebel-i Tûr) was a Syriac vernacular, Turoyo, spoken. Moreover, the written Syriac language was simply not known by enough people to make it practical for use in the media. Ottoman Turkish was by no means universally spoken, but at the same time, unlike Armenian and Arabic, it was not perceived negatively in the community as being a "foreign" tongue. ${ }^{10}$ Kurdish was much less frequently written, although there are suggestions that it may have made the occasional appearance in Süryân $̂$ publications. ${ }^{11}$

Another related feature of the Süryâñ press was the use of mimeography rather than type-setting for the reproduction process. With the exception of el-Hikmet, all of the pre-1914 publications (as well as the later, but influential, Bethnahrin) were hand-written and then printed with a mimeograph machine. Partially this was due to the greater difficulty in casting the western Syriac alphabet but it should also be noted that the Ottoman publications were each the endeavour of a single person whose time was divided between journalism and another profession. Again el-Hikmet is peculiar in that it had the support of the Syriac Orthodox Church, being printed on its press at Deyrü'z-Zaferân. Two short-lived Harput publications, Hayât and Kevkbo d-Sûryoye, were also established by members of the clergy, although it is not clear that they received

9 In the Süryân̂ิ cemetery in Elâzığ (near Harput) only a few gravestones from the nineteenth and twentieth centuries show Ottoman Turkish in the Syriac alphabet.

10 Âşûr Yûsuf, one of the journalists discussed below, related the existence of such a perception amongst the Süryânî.

11 At least one Bible was printed in Armenian using the Syriac alphabet, but I have not been able to find other such examples. 
official support or sanction from the Church. A number of other periodicals had affiliations with Süryânı̂ organisations, however. Most notable were the monthly Intibâh, which had ties with the Terakkiyât-ı Mekteb-i Süryânî Cemiyeti [Association of Progress for Süryanî Schools], ${ }^{12}$ and Savto d-Oromoye, which was published by the local branch of the Intibâh Cemiyeti [Association for the Awakening]. ${ }^{13}$

The Süryân $\mathbf{p}$ press appears to have been successful in garnering an involved and enthusiastic readership in a short time, and despite not being a large community, by 1914 it could boast five active publications. Thanks to the publication of subscriber lists, we are aware of a readership throughout the Ottoman Empire (including places such as Istanbul, Kosovo, Salonica, Samsun, Mosul, Jerusalem, Baghdad, Egypt, and Beirut besides the core areas of Süryân settlement). There were also numerous subscribers in the United States and Canada, and the Harput-based Mürşid-i Âsûriyûn even had a community member in Worcester, Massachusetts handle subscriptions from North America. In addition, we have records of subscribers in Tbilisi, Buenos Aires, and even India. ${ }^{14}$ Similar records indicate that the periodicals located in the United States were also widely read throughout the Ottoman Empire. Unfortunately, despite the encouraging breadth of readership, the publishers often expressed their dire financial situation, something which was compounded by the chronic failure of subscribers to pay their fees.

There was, however, some cause for optimism right up until the outbreak of the First World War. After five years of hardship and thoughts of closing his Mürşid-i Âsûriyun, Âşûr Yûsuf announced in late 1913 that he had collected enough funds to finally purchase cast type for the coming year. Making this investment, Âşur Yûsuf suggests that even at this late date, the future of the Süryân $\hat{\imath}$ was to be in the Ottoman Empire as Ottoman citizens. Such expectations had, in some cases, given way to disappointment of the growing autocratic rule of the Ittibâd ve Terakkế Cemiyeti and the backlash against non-Muslims following the Italian invasion of Libya and the Ottoman losses in the Balkan Wars; Naûm Fâik,

12 The association is now better known by the initials T. M. S.

13 The notion of an "awakening" (intibâh) tied to the 1908 revolution may be found in the thought of all Süryânî institutions of the early twentieth century, so there should be no surprise that two of them took the name Intibâh.

${ }_{14}$ Also interesting is the fact that Mürşid-i Âsurriyun and Intibâh made use of the English-language press in India as a source of information on the activities of Patriarch Abdullah and former Patriarch Abdülmesîh. 
perhaps the most famous Süryânî journalist, chose to leave Diyarbakır for New Jersey in 1912. Two of the remaining Süryânî journalists, Âşûr Yûsuf and Beşâr Hilmî, would be caught up in the killing of Christians of the eastern parts of the Empire, the hopes that their community had placed in the Ottoman state ending with them.

Wartime Süryân $n$ journalism was characterised by a swing in the opinions of the emigrant communities towards an Assyrian nationalism which fully incorporated members of the Church of the East and the Chaldean Catholic Church. The first joint publication, Huyodo, was edited by Naûm Fâik and was the official organ of the Assyro-Chaldean National Unity of America. At the same time there was a slow shift away from using Ottoman Turkish for the names of organisations and publications, something which was likely a product both of this increasing unity and a rejection of things Ottoman and Turkish as the audience of Syriac journalism grew to encompass the greater Assyrian community, in which Turkish was a minority, not a majority, language. With the end of the Ottoman Empire and the near elimination of a Süryânî community in Turkey, the use of the language declined further. This was compounded by Turkey's adoption of the Latin alphabet in 1928 and then the "reform" of Ottoman Turkish, producing the modern Turkish language. Süryân̂ि survivors of World War I were concentrated in Arabic or English-speaking countries and were left with the option of retaining the dying Ottoman language or embracing the tongue of their adopted countries.

\section{BIBLIOGRAPHY}

The bibliography of Ottoman Turkish-language periodicals will include some basic details including the editor, place of publication and rates for a year's subscription. In the language section, the alphabet employed for Arabic and Ottoman Turkish will be indicated by (A) for Arabic and (S) for Syriac. Known issues to have survived, as originals or in copy, will be given under the headings of (NYPL) for the New York Public Library, (WL) for Harvard's Widener Library, (MA) for the Metropolitanate of Aleppo and $(\mathrm{KK})$ for the library at the Kirklar Kilisesi in Mardin. In addition, the private collections of George A Kiraz and Jan Bet-Şawoce will be indicated by (GAK) and (JBŞ) respectively. Other small collections are known to exist but as yet I have not been able to catalogue their contents. 


\section{THE OTTOMAN EMPIRE}

حind̦r aris Mürşid-i Asûriyun [Guide of the Assyrians] ${ }^{15}$

Editor: Âşûr Yûsuf

Place: Harput

Years: 1909-1914

Language: Ottoman Turkish (S)

Frequency: 1 issue / month

Pages: 16

Rates: 12 guruşs (Harput); 15 gurûs (domestic); \$1 (United States)

Issues (GAK): vol. 6 (1914), 1-2

Issues (JBŞ): vol. 3 (1911), no. 1-12; vol. 4 (1912), 1-13; vol. 5 (1913), 1-13

Issues (KK): probably identical to those held by (JBŞ)

The first Süryânî publication, Mürşid-i Âsûriyûn is well-known in the present-day Assyrian scholarship. Its target audience has often been incorrectly assumed to be the greater Assyrian community, when it was in fact that of the Süryânî alone. Âşûr Yûsuf was a professor of classical Armenian at the Euphrates College, an American mission school. Mürşid-i Asûriyun made open its attempts to reach as many readers as possible by employing a simplified Ottoman Turkish more easily understood by a public without great access to education. Despite not having any affiliations himself, Âşûr Yûsuf closely followed the activities of Süryânî charitable organisations and educational institutions throughout the Ottoman Empire and in the United States. Âşur Yûsuf was also involved in a protected dispute with mutrân of Harput, Abdünnûr (see Kevkbo d-Sûryoye below), which resulted in a series of unsuccessful court cases being brought against Mürşid-i Âsûriyûn. Âşûr Yûsuf, along with the Armenian professors from the Euphrates College, was imprisoned and then killed by the Ottoman authorities during the First World War.

Kevkeb Mednho [Star of the East]

Editor: Naûm Fâik

Place: Diyarbakir

Years: 1910-1912

Language: Arabic (S); Ottoman Turkish (S); Syriac

Frequency: 1 issue / 2 weeks

Pages: 8

15 There is evidence that early volumes were issued under the name Mürsidï̈l-Âsûriyûn, the Arabic equivalent of the Farsi Mürşid-i Âsûriyûn. 
Rates (vol. 1): 18 gurûş (Diyarbakır); 20 gurûş (domestic); 25 gurûs (international)

Rates (vol. 2): 20 gurûs (Diyarbakır); 25 guruss (domestic); \$1.50 (United States)

Issues (GAK): vol. 1 (1910-1911), no. 7; vol. 2 (1911-1912), no. 7 9,12

Issues (JBŞ): vol. 1 (1910-1911), no, 2, 16, 18-20, ${ }^{16}$ 22, 24; vol. 2 (1911-1912), no. 3

Issues (NYPL): vol. 1 (1910-1911), no. 1-26; vol. 2 (1911-1912), $1-14$

At the time of his first journalistic endeavour, Naûm Fâik (properly Naûm İlyâs Palak) was a teacher at the Süryân̂ि school in Diyarbakır and had recently founded the Intibâh Cemiyeti, an educational and charitable organisation which would come to have branches in all major areas of Süryânı̂ settlement, including the United States. The publication of Kevkeb Mednho was supported by Beşâr Hilmî (see Sîfûro below). Despite its short period of existence, it achieved great renown within the community, with subscription records suggesting that Kevkeb Mednho was the most widely read of the Süryânî publications in the Ottoman Empire. Naûm Fâik emigrated to the United States in 1912, when he would continue his involvement in journalism.

l;as, l: Safro d-Nûbro [Light of the Dawn]

Place: Harput?

The first issue of Hayat made reference to this publication in an open letter addressed to an individual who had contributed articles to Safro d-Nûhro and Mürşid-i Âsuriyun. The text only reveals that he was the nephew of a meyhaneci [tavernkeeper] Donabed, the Donabeds being a family from Harput.[footnote remains here] The connections with Harput suggest that Safro d-Nûbro might have also been published there. ${ }^{17}$

Kevkbo d-Sûryoye [Star of the Süryâmi]

Editor: mutrân Abdünnûr

Place: Harput

Years: 1910

${ }^{16}$ Issues 18 through 20 are missing the initial two pages.

17 By this time there were also Donabeds in the United States, so it may have been published there. 
Language: Arabic (S); Ottoman Turkish (S); Syriac

Pages: 9

Issues: (JBŞ): vol. 1 (1910), no. 4

Intibâh (June 1910) and Kevkeb Mednho (August 1910) made mention of Kevkbo d-Sûryoye but it is known from Mürsid-i Asturiyun that the publication did not survive past the end of the same year. Of the little information available, the most striking is the fact that it was published by the mutrân of Harput, Abdünnûr, making him the most senior member of the clergy to have engaged in journalism. In the only issue known to have survived, there are nine pages, all of which are written in Ottoman Turkish.

drrev Hayât [Life]

Editor: keşî̧ Pavlus

Place: Harput

Years: 1910

Language: Ottoman Turkish (A, S)

Frequency: 1 issue / 2 weeks

Pages: 4

Issues (JBŞ): vol. 1 (1910), no. 4

Little is known about Hayat other than references to its third and fourth issues in Kevkeb Mednho (November 1910) and to its closure in Mürşid-i Assuriyun at the end of the same year. While Hayât was entirely Ottoman Turkish, two pages were printed in the Syriac alphabet and the other two pages contained the same articles rendered in the Arabic alphabet.

jo@a Şîfûro [Trumpet]

Editor: Beşâr Hilmî Borucu

Place: Diyarbakır

Years: 1910-1914

Language: Ottoman Turkish (A, S)

Frequency: 1 issue / 2 weeks

Pages: 4

Rates: 15 gurûş (Diyarbakır); 17.5 gurûs (domestic); 25 gurûs (international)

Issues (GAK): vol. 1 (1913), no. 3

Issues (JBŞ): vol. 1 (1911), no. 1; vol. 1 (1913), 11

After having provided it with financial support and numerous articles by his own hand, Beşâr Hilmî closely modelled his own 
publication on Kevkeb Mednho, with the same dimensions, layout, and frequency of publication. Besides only having four pages, the major difference was its exclusive reliance on Ottoman Turkish, sometimes written in the Arabic alphabet. There is some confusion with respect to the form in which Siffurro appeared over the years since issues from both 1911 and 1913 were indicated as belonging to Volume 1. Beşâr Hilmî would be killed on the outskirts of Diyarbakır in late 1914.

el-Hikmet [Wisdom]

Proprietor: Hannâ el-Kıs

Editor: Mîhâil Çakkî

Place: Mardin

Years: 1913-1914

Language: Arabic (A), Ottoman Turkish (A), Syriac

Frequency: 2 / month

Pages: $12-16$

Issues (GAK): vol. 1 (1913-1914), no. 1-3, 5-24

Issues (KK): vol. 1 (1913-1914), no. 1-24

In several ways el-Hikmet differed from other Süryânî publications. Firstly, it was printed at the monastery of Deyrü'z-Zaferân outside of Mardin, the seat of the Syriac Orthodox Patriarch, and had close ties to the religious establishment. Secondly, el-Hikmet was typeset in its entirety (including the Syriac portions) rather than being mimeographed. Finally, it was almost entirely in Arabic, with only the occasional article in Syriac and even fewer in Ottoman Turkish, the latter usually being official documents or statements. After only a year, el-Hikmet closed; however, Mîhâil Çakkî would reopen the journal in Jerusalem in the 1920s, publishing it for another five years. ${ }^{18}$

\section{THE UNITED STATES}

a) Ini Intibâh [Awakening]

Editor: Cebbûr Boyac1 [Gabriel Boyaji]

Place: College Point, New York

Years: 1909-1915

Language: Arabic (S), Ottoman Turkish (A, S), Syriac

Frequency: 1 / month

18 Gabriyel Akyüz, Tüm Yönleriyle Süryaniler (Mardin: Kırklar Kilisesi, 2005), 300-302. 
Pages: 8

Rates: \$1 (United States); 25 gurûs or \$1.10 (Ottoman Empire)

Issues (GAK): vol. 1 (1909-1910), no. 4-9, 11; vol. 2 (1910-1911), no. 14-15, 23-24; vol. 3 (1911-1912), no. 26, 28, 30-36; vol. 4 (1912-1913), no. 37, 39, 44-45, 47-48; vol. 5 (1913-1915), no. 49$50,54,56$

Issues (JBŞ): vol. 1 (1909-1910), no. 5; vol. 2 (1910-1911), no. 13

Issues (NYPL): vol. 1 (1909-1910), 1-12; vol. 2 (1910-1911), no.13-24; vol. 3 (1911-1912), no. 25-36; vol. 4 (1912-1913), 3748; vol. 5 (1913-1915), 49-57

Issues (MA): vol. 1 (1909-1910), 1-2, 5-12; vol. 2 (1910-1911), no.13-24; vol. 3 (1911-1912), no. 25-36; vol. 4 (1912-1913), 3748; vol. 5 (1913-1915), 49-56

Diyarbakır native Cebbûr Boyacı established his influential Intibâh in association with the Terakkizât-ı Mekteb-i Süryânî Cemiyeti. ${ }^{19}$ Naûm Fâik was a frequent contributor to Intibâb both while in Diyarbakır and after his arrival in the United States. Its articles were also frequently cited in the Süryânî periodicals in the Ottoman Empire. The first issue was written entirely in the Arabic alphabet but only in one later issue would Intibâh ever make use of anything but Syriac letters; non-Ottoman Turkish articles were exceedingly rare. Starting in its second year of existence, Intibâh bore the English subtitle “Assyrian's [sic] Monthly Newspaper.” İntibâh was published on schedule except for December 1913 and the interval between August 1914 and January 1915, when issues did not appear. Following its closure in March 1915, Intibâh would be reopened by Naûm Fâik as Bethnabrin in 1916.

Loiji? ILo, Savto d-Oromoye [Voice of the Aramaeans]

Editor: Senharîb Bâlî

Place: Paterson, New Jersey

Years: 1913-?

Language: Ottoman Turkish (S)

Savto d-Oromoye (erroneously referred to as Voice of the Assyrians in most sources) is significant as it is said to have been the publication of the Intibâh Cemiyeti established by Naûm Fâik in Diyarbakır. ${ }^{20}$

19 Ibid., 296.

20 Senharîb Bâlî's personal notes written some decades later did indeed refer to Savto d-Athoroye, but in the same notes he also recorded the titles of several Süryânî periodicals (for example, Intibâh and el-Hikmet) in 
The inauguration of Savto d-Oromoye and a few basic details were announced in Mürşid-i Âsûriyûn but no issues are known to have survived. Also in 1913, Intibâh accused Savto d-Oromoye of being an Armenian mouthpiece for having taken an Armenian from Diyarbakir as an editor. Other sources state that the editor was Senharîb Bâlî, also from Diyarbakır, who would go on to be a contributing editor at Huyodo.

\section{مirshe Bethnahrin [Mesopotamia]}

Editor: Naûm Fâik [Naoum E. Palak]

Place: Paterson, New Jersey; Central Falls, Rhode Island

Years: 1916-1933

Language: Arabic (S), Ottoman Turkish (S), Syriac

Frequency: 1 / 2 weeks

Rates: $\$ 2.50$

Issues (KK): vol. 1-10

Issues (NYPL): 1916:3:8-1917:9:8/22; 1927:1:1-2/3; 1932:721

Issues (WL): vol. 1, no. 13-18; vol. 2, no. 5-6, 9-10, 15-16; vol. 3, no. 1-9, 11; vol. 4, no. 3-6; vol. 5, no. 2-3, 6-7; vol. 6, no. 1; vol. 13, no. 8; vol. 14, no. 1-11; vol. 16, no. 1-9

Naûm Fâik established Bethnabrin in 1916 following the closure of Intibâh, to which he had been a contributor. Publication only stopped for the period during which he worked on Huyodo. After 1926, when Naûm Fâik stopped working on Bethnahrin, the publication began appearing out of Central Falls. Bethnabrin's English subhead, "the Assyrian paper," was nearly identical to that of Intibâh, but it differed in that it rejected the support for the Ottoman state which had been typical of Süryanı journalism prior to World War I.

\section{The New Assyria}

Editor: Joel E. Werda

President and manager: Charles Dartley

Place: Jersey City, New Jersey

Years: 1916-1919

Language: English, Ottoman Turkish (S)

Syriac despite the fact that they were not so named. We should understand such conscious changes as being part of the shift towards an entrenched Assyrian identity which characterized the Süryânî in the United States following World War I.

${ }^{21}$ The records for Bethnabrin at NYPL are given as listed in the library catalogue since I have not been able to examine them myself. 
Frequency: 1 / month

Pages: $12-14$

Rates: $\$ 1.00$ (United States); $\$ 1.50$ (Canada); $\$ 2.00$ (international)

Issues (NYPL): vol. 1 (1916-1917), no. 1-12; vol. 2 (1917-1918), no. 13-24; vol. 3 (1918-1919), no. 25-34

Issues (WL): vol. 1 (1916-1917), no. 2, 7, 9-12; vol. 2 (1917-1918), no. 14, 18-21, 23-24; vol. 3 (1917-1918), no. 27-31, 33-34

Joel E. Werda also published the Assyrian American Courier, but The New Assyria specifically targeted the Süryânî emigrant community in the United States. The publication was almost entirely in English but occasionally included an Ottoman Turkish supplement.

fupting Babelon [Babylon]

Editor: (Naûm?) Beşârûf

Place: Boston

Years: 1919-1921

Language: Armenian, English?, Ottoman Turkish?

Frequency: 1 / month

Issues (WL): vol. 1 (1919-1920), no. 1-27; vol. 2 (1920-1921), no. $1-27$

Little is known about Babelon although its use of Armenian and its publication in Massachusetts suggests that it had a Harput connection.

Kions Huyodo [The Union]

Publicity manager: Charles S. Dartley

Editor: Naom Elias Palak

Place: New York City

Years: 1921-1922

Language: Arabic (A), English, Ottoman Turkish (S), Syriac

Frequency: 1 / week

Pages: 4

Rates: $\$ 5.00$

Issues (NYPL): vol. 1 (1921-1922), no. 1-36, 38-39

Unlike previous Süryân 1 publications, the self-described organ of the Assyro-Chaldean National Unity of America, Huyodo brought all the different peoples together under a single Assyrian banner. Naûm Fâik ceased publication of Bethnabrin so as to work as an editor for Huyodo although in this case he had several assistants. Huyodo is also 
remarkable for its professional typesetting of both the eastern and western Syriac scripts in addition to the Arabic and Latin alphabets.

\section{LEBANON}

Rhsars il Leşono d-Umto [Voice of the Nation]

Editor: İbrâhîm Hakverdi

Place: Beirut

Years: 1927-?

Language: Arabic (A), Ottoman Turkish (S)

Frequency: 2 / month

Pages: 4

Rates: SL $f 300$ (Syria and Lebanon); $\$ 5$ (international)

Issues (GAK): vol. ? (1933), no. 37; vol. 8 (1939), no. 148

Issues (JBŞ): vol. 1 (1927-1928), no. 1; vol. 4 (1929-1931), no. 63, 65

Issues (WL): vol. 1 (1927-1928), no. 1-24; vol. 2 (1928-1929), 2548; vol. 3 (1929), 49-61; vol. 4 (1929-1931), 62-79; vol. 5 (19311932), $81-83,85^{22}$

Lesono d-Umto would be the last Süryânî publication to use Ottoman Turkish. Some issues were uniquely in Arabic and had an Arabic title (Lisânü'l-ümmet]) alongside the Syriac. Leşono $d$-Umto continued appearing until World War II or shortly thereafter.

\section{REFERENCES}

Akyüz, Gabriyel. Tüm Yönleriyle Süryaniler. Mardin: Kırklar Kilisesi, 2005.

BarAbrahem, Abdulmesih. “The 'Question of Assyrian Journalism' Revisited." Journal of the Assyrian Academic Society 9, no. 1 (April 1995): 3-7.

Benjamin, Yoab. “Assyrian Journalism. A 140-Year Experience.” Journal of the Assyrian Academic Society 7, no. 2 (November 1993): 1-28.

Naby, Eden. "The Assyrians of Iran: Reunification of a 'Millat,' 19061914." International Journal of Middle Eastern Studies 8, no. 2 (April 1977): 237-249.

Naby, Eden and Michael E. Hopper. The Assyrian Experience: Sources for the Study of the 19th and 20th Centuries. Cambridge, Massachusetts: Harvard College Library, 1999.

Yonan, Gabriele. Journalismus bei den Assyrem. Ein Überblick von seinen Anfängen bis zur Gegenwart. Berlin: Zentralverband der Assyrischen Vereinigungen in Deutschland und Mitteleuropa, 1985.

22 I have only observed the issues in the JBŞ collection, so I can not account for the discrepancies in the volume and issue numbers. 